\title{
Biogas Energy and Livelihood Sustainability Within Rural Households in the North West Region of Cameroon
}

\author{
RiddleyMbiybeNgala ${ }^{1}$, LovelineKongla Nsahlai ${ }^{2}$, AnastasiaKininla Kongnyuy ${ }^{3}$, and HarryMairomi Wirngo ${ }^{4}$ \\ ${ }^{1,3}$ Geography Department, The University of Yaounde 1, Cameroon \\ ${ }^{2}$ Geography Department, Higher Teacher Training College, Bertoua, Cameroon \\ ${ }^{4}$ Department of Geography, Higher Teacher Training College,Bambili, Cameroon
}

\begin{abstract}
Apart from road, water and health difficulties, energy more especially fuel is amongst the issues rural dwellers have to grapple with in their quest for sustainable livelihood. Biogas energy was introduced in Cameroon in the 1970s. In this paper we intend to demonstrate how biogas energy is primordial in sustaining livelihoods in rural areas as a substitute to traditional fuel wood through its environmental, economic and social advantages. To carry out the study we conducted a sample of biogas users in the North West Region of Cameroon. Then we administered questionnaires to identified users followed by interviews and observation of the putting in place of these schemes.We therefore argue that biogas energy schemes can sustain livelihoods in rural areas as the slurry is used in farms for crop cultivation; its use reduces drudgery and improves the health of its users. Our findings equally reveal that the use of biogas energy mitigates the effects of deforestation as well as help in the fight for environmental protection.Further research is required to render such initiatives efficient by upgrading its performance with the required technological know-how as well as diversify its uses from not only a source of fuel but should equally be rendered more flexible.
\end{abstract}

Keywords:- Biogas energy, rural livelihood, sustainability, North West Region-Cameroon.

\section{INTRODUCTION}

Nowadays, in the World, energy is fundamental in sustaining the quality of life, ensuring better living, economic production, growth, and employment. Any shortage in energy supply to the national economy could disrupt the economic process and livelihood of the people [1]. Today, developing countries have an interest in the development of renewable energy and particularly in the generation of biofuels [2]. In Cameroon, there has been growing demand for 'new' energy sources; Cameroon's population has for long depended on Hydro-Electricity Power (HEP) with the creation of 'la SociétéNationale de l'Electricité (SONEL) in 1960. Despite measures taken by the government to revive this sector and meet with the increasing population's demand, most rural households have not been supplied with HEP energy. However, Small scale electricity and energy production is increasingly being solicited by a good number of Cameroonians especially those in remote and enclaved areas of the country [3]. Biogas energy generation has been one of the renewable energies (REs) offered as an alternative to Cameroonians especially those living in the rural milieus of the North West Region of Cameroon (NWRC).

Biogas is a mixture of methane and carbon dioxide produced by bacterial degradation of organic matter and used as fuel. It results from anaerobic liquefaction and digestion of organic matter by micro-organisms [4]. In this same line, [5], define biogas as a combustible mixture of gases comprising mostly of methane $\left(\mathrm{CH}_{4}, 55 \%-70 \%\right)$, Carbon dioxide $\left(\mathrm{CO}_{2}, 24 \%-44 \%\right)$, Hydrogen Sulphide $\left(\mathrm{H}_{2} \mathrm{~S}\right)$, Hydrogen and ammonia ( $1 \%-2 \%$ each), Carbon monoxide, Nitrogen and Oxygen in trace amounts. Introduction of biogas affects livelihood of people as a cheap and convenient energy source principally used for cooking and heating while also providing organic manure for soil fertility. According [6], in an era of climate change mitigation and adaptation; and in cases of severe energy insecurity where the use of fossil fuels becomes restricted, using biofuels produced under low intensity, small scale and conservative eco-agricultural system can contribute to emerging renewable energy demands.

In recent years there has been a significant development of agricultural biogas plants as compared to other renewable energy sources; [7] and [8].According to [6], biogas contributes to sustainable development goals such as carbon emission reduction, elimination of rural energy poverty, poverty alleviation through provision of new rural energy jobs, and more integrated rural development.Meanwhile [9], upheld that Biogas technology is considered as one of the lowest cost renewable energy sources for rural areas. According to [10], Loas governmentviews biogas as a vehicle to reduce poverty of rural households and as an alternative source of low-cost renewable energy for rural households or low income farmers.

The production of agricultural biogas requires a daily supply of feedstock, namely the substrates for energy production coming from target crops as well as increasing byproducts and agro food waste [12]. The NWR is one of the regions in Cameroon where agriculture is practiced; substrate giving plant such as maize is highly cultivated and animal rearing practiced. These provide the basic inputs into the system and goes in line with[1] who opined that 
ISSN No:-2456-2165

Biogas production and consumption induces significant socio-economic and environmental impacts on the livelihoods of rural dwellers.

\section{RESEARCH METHODOLOGY}

\section{A. Location of study area}

The study area lies between latitudes $5^{\circ} 40^{\prime}$ and $7^{\circ} 00^{\prime}$ north of the equator and longitudes $9^{\circ} 45^{\prime}$ and $11^{\circ} 10^{\prime}$ east of the Greenwich meridian. It is bordered to the north bythe Federal Republic of Nigeria, to the south by the West Region of Cameroon, to the East by the Adamawa Region of Cameroon and to the West by the South West Region of Cameroon (figure 1).The North West Region of Cameroon is made up of seven Divisions; Mezam, Boyo, Ngoketunjia, Bui, Mechum, Momo and Donga-Mantung.

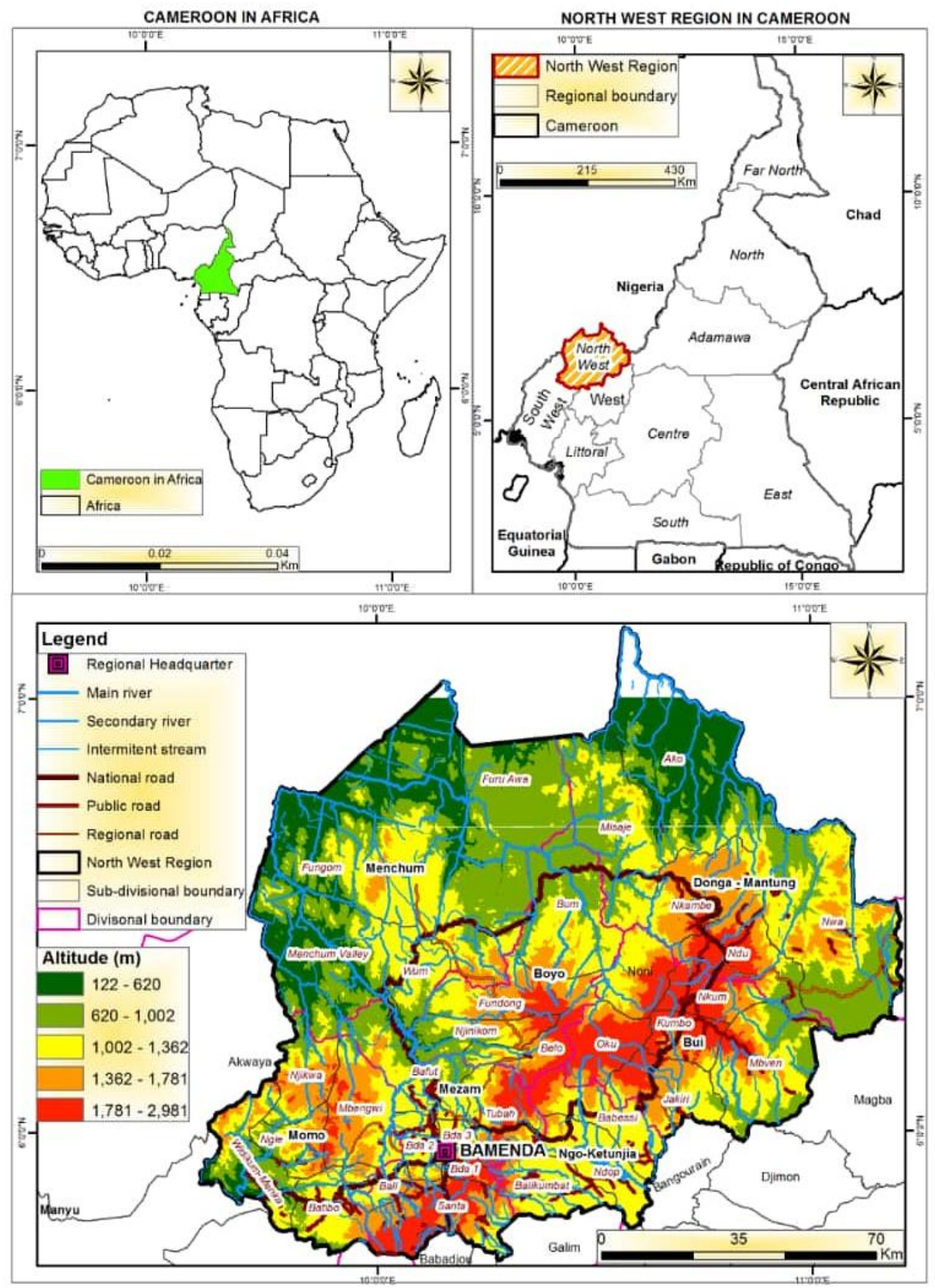

Fig 1a:- location of the NWR in Africa and Cameroon.

Source: Atlas of Cameroon, 2016. 


\section{B. Methods and techniques}

Amongst the seven Divisions of the NWRC, biogas energy production is practiced in three Divisions; Mezam, Boyo and Bui. Information and statistics on biogas energy was obtained from Cameroon's Ministry of Environment where it was revealed that biogas energy was launched in the NWRC in collaboration with Hiefer Project International. Through this NGO, we have been able to identify biogas plants. SHUMAS (Strategic Humanitarian
Services) and SNV (Netherlands Development Organisation) equally served as resource centers for biogas activities in the study area. A random sampling technique was used to select the sample size of households with biogas plants. Quantitative and qualitative data was collected through questionnaires, interviews and observation.Seven localities in the three divisions cited above are concerned: Mendakwe, Santa, Vekovi, Wainamah, Bamdzeng, Kingomen and Dumbu (table 1).

\begin{tabular}{|l|l|l|l|}
\hline Number & Locality & Total number of households & Surveyed households \\
\hline 1 & Bamdzeng & 84 & 4 \\
\hline 2 & Dumbu & 871 & 43 \\
\hline 3 & Kingomen & 390 & 18 \\
\hline 4 & Mendakwe & 123 & 06 \\
\hline 5 & Santa & 1779 & 36 \\
\hline 6 & Vekovi & 1080 & 21 \\
\hline 7 & Waiynamah & 448 & 22 \\
\hline & TOTAl & 4775 & 150 \\
\hline
\end{tabular}

Table 1:- Localities and number of surveyed households

Source: BUCREP, 2005; Heifer Project International; \& SHUMAS, 2016.

After choosing the sample size of 150 households, questionnaires were administered to them. AGPSwas used to locate biogas energy schemes and their distribution in the Region. This tool permitted us to have precise geographic positions where biogasschemes are found. A digital camera helped in taking photographs in the field. The schemes as well as other important features observed were illustrated using photos.

\section{RESULTS AND DISCUSSION}

\section{A. Crop cultivation}

Biogas does not only reduce the amount and cost of firewood or charcoal, dung residual is used as a substitute for chemical fertilizer which reduces cost. Biogascropping-livestock integration has the potential to improve livelihoods of small holders in rural areas with lower costs for agricultural production and living expenses along with higher environmental quality [10].According to Cerda et al (2017) cited by [11], the waste of byproducts of substrates and dung used in biogas production are free of charge or the cost of obtaining them is generally low. With biogas installations in rural milieus of the NWRC, the use of chemical fertilizers which is expensive for most rural households to obtain has been substituted with the use of organic waste at low costs from biogas installation plants. However, $59 \%$ of rural households that could not afford to buy chemical fertilizers for their farms so as to increase yields, now use organic manure which is less costly and sometimes obtained free; this, however, increases output.

According to [12] and[13], slurry from $1 \mathrm{~kg}$ of digested dung can yield up to extra $0.5 \mathrm{~kg}$ nitrogen compared to fresh manure. Also, [14], affirms that it is estimated that the use of bio-slurry annually saves $39 \mathrm{~kg}$ of Nitrogen, $19 \mathrm{~kg}$ of phosphorous and $39 \mathrm{~kg}$ of potassium per household. In this same line, [15, 16], assert that fertilizer produced from biogas digesters is of good quality (rich in
Nitrogen, Phosphorous and Potassium contents) and it is used as soil manure to improve micro-flora and building the soil structure and texture. All these elements are responsible for improving soil fertility and enhancing crop growth. This shows that organic manure from biogas production byproducts improves soil fertility than organic manure that has not been processed. In the study area, farmers (men and women) have been sensitized by Heifer Project International (HPI) training team on the importance of manure gotten from biogas processing over the usage of synthetic fertilizers and organic manure gotten directly from plants and animals waste; with this knowledge, farmers have become more interested in the usage of biogas byproducts as organic manure.

The study revealed that $91 \%$ of farmers in the study area who have access to biogas byproducts for organic manure have witnessed a change in the quality and quantity of their agricultural outputs. Field investigation shows that dung from $3-5$ cows or $8-12$ pigs in a simple $8-10 \mathrm{~m}^{3}$ biogas plant can produce $1.5-2 \mathrm{~m}^{3}$ of gas and 100litres of slurry (Bio fertilizer) per day. The manure derived greatly enriches soil fertility as maize for instance produces 12 tons per hectare more than non-organic farms that yields 8 tons per hectare.Bio-slurry use can solve problems of soil degradation in areas where dung has been used as a burning fuel and implies that less artificial fertilizers has to be bought; so, biogas manure saves money that could have been used in the purchase of synthetic fertilizer thus upgrading revenue to the household [17, 18]. Proper application of bio-slurry instead of expensive synthetic fertilizers improves soil structure and fertility which boast the productivity of agricultural plots [19].

In the NWRC, the slurry that comes out from the biogas system is used as fertilizers, insecticides and as local mulchduring the dry season. Field evidence in Santa, Bamendakwe, Vekovi and Bamdzeng indicated that yields 
and quality of agricultural production has increased significantly due to the adoption of biogas technology. Yields of huckleberry increased from 3 bags (100kg size) per week to 7 bags, followed by a corresponding increase in cabbage from $4-8$ bags $(100 \mathrm{Kg})$ after the introduction of slurry in a 0.4 hectare farm as revealed by field findings. Similar resultswere noted in aSHUMAS farm where output of corn and vegetables increased by about $40 \%$ after the application of slurry in the fields.

\section{B. Reduction in drudgery}

According to $[16,15]$, reduction in fuelwood consumption as a result of biogas installation plants have reduced fuelwood consumption and this has also reduced the drudgery of women and children in collection of fuelwood which enables them to carry out other productive
activities.SHUMAS demonstration farms show that 1 cow yields: 9 - 15kg dung/day (producing $0.4 \mathrm{~m} 3$ gas /day) while 1 pig yields: $2-3 \mathrm{~kg}$ dung /day(producing $0.15 \mathrm{~m} 3$ gas/day). Cattlerearing is the dorminant land use in the region and provides a good source of input with the other livestock types. Biogas reduces workload including reduced time in collecting firewood, cooking and cleaning of cooking utensils[10].Women and children in the NWRC have been noticed to cover longer distances in search for fuel wood in montane woodlands which at times results in conflicts. To supplement fuelwood and produce electricity transmission poles in this part of the country, there is the planting of eucalyptus trees referred to by many as an "environmental terrorist" with its associated consequences on watersheds. Plate 1shows women using biogas energy in Santa and Bamendakwe instead of fire wood or fuel wood.

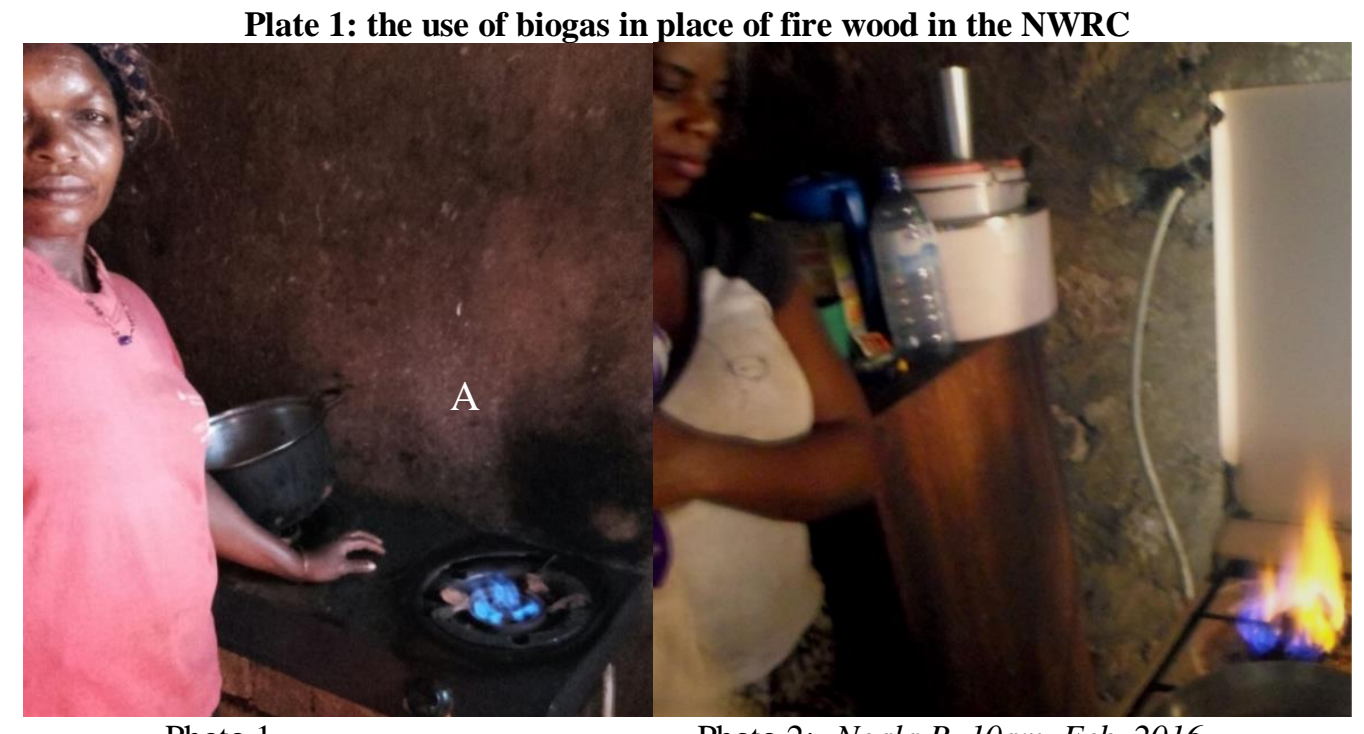

Photo 1

Photo 2:- Ngala R, 10am, Feb. 2016.

Photos 1 and 2:- illustrates the use of Biogas in 2households in the localities of Santa and Bamendakwe. These families dropped the use of fire wood for cooking and embarked in using biogas

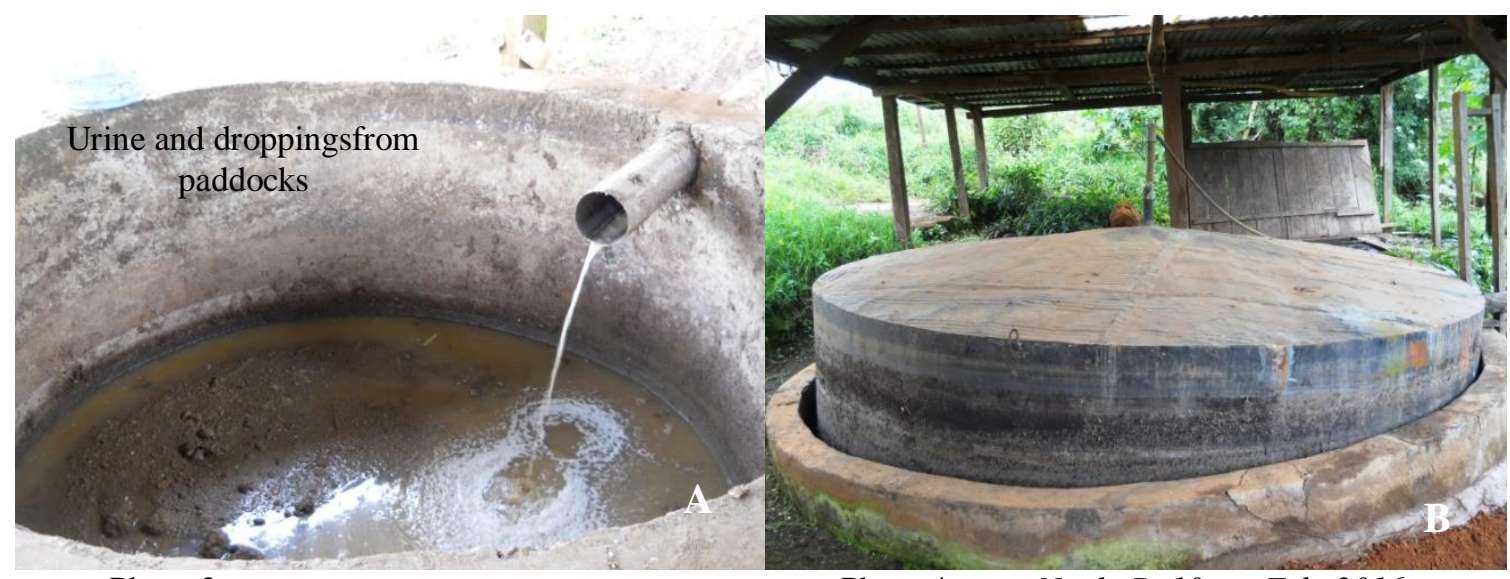

Photo 3

Photo 4

Ngala R, 10am, Feb. 2016.

Photo 3\&4:- Biogas system: A-tank where animal droppings are mixed connected to digester;

B-Floating biogas digester, indicates the level floating which signifies the level of gas available in the digester 
The fact that the NWRC is part of the grass fields with savannah vegetation makes it difficult for fuel wood gatherers to easily obtain fuel wood for cooking. In this light biogas energy has been adopted by some communities in the region in a bit to remedy "fuel wood crisis. The fuel used by households is actually not "free" but rather is nonmonetized, because no value is assigned to the labour of the women and children who gather it [20].In this light, if this labour was properly valued and the health damage costs of solid fuel internalized, solid fuel would be far more expensive than modern clean cooking fuels (biogas).

\section{Economic benefits.}

Biogas energy has experienced remarkable improvement in the NWRC. Users of this energy type use biogas for cooking and heating in households, hospitals, schools and prisons. According to [6] biogas alleviates poverty through provision of new rural energy jobs and more integrated rural development.The production of biogasbenefits the Africancommunity as the socioeconomic and environmental impact portrayed by these energy type on African countries depend on the amount of clean and renewable energy they can produce. Biogas has been at the rescue of most developing countries in subSaharan Africa; Cameroon in particular and precisely the NWRC to overcome "energy poverty" which is a common phenomenon in remote communities and stands as a barrier to the socio-economic development of the region. Biogasschemes in the NWRC have been evaluated from diverse angles to determine its impact. In the field there is strong evidence as to the fact that this scheme has strong immediate effects on consumers through the betterment of living conditions.In the study area, income gaining activities as a result of biogas were identified and their income levels measured as depicted in the table 2.

\begin{tabular}{|c|c|c|c|c|c|c|}
\hline \multirow[b]{2}{*}{ Biogas user } & \multirow{2}{*}{$\begin{array}{l}\text { Number } \\
\text { before biogas } \\
\text { production } \\
\text { period }\end{array}$} & \multirow{2}{*}{$\begin{array}{c}\text { Number } \\
\text { during biogas } \\
\text { production } \\
\text { period }\end{array}$} & \multirow{2}{*}{$\begin{array}{l}\text { Average monthly } \\
\text { expenditure } \\
\text { before biogas } \\
\text { production. } \\
\text { (before 2003) }\end{array}$} & \multicolumn{2}{|c|}{$\begin{array}{c}\text { Expenditure during biogas } \\
\text { generation } \\
(2003+)\end{array}$} & \multirow{2}{*}{$\begin{array}{c}\% \text { Increase in } \\
\text { income as a result } \\
\text { of biogas } \\
\text { production. }\end{array}$} \\
\hline & & & & $\begin{array}{l}\text { Average } \\
\text { Monthly } \\
\text { spending } \\
\text { (CFAF) }\end{array}$ & $\begin{array}{c}\text { Income } \\
\text { gained/Monthly } \\
\text { (CFAF) }\end{array}$ & \\
\hline Hospitals & 00 & 02 & 75000 & 25000 & 50000 & 67 \\
\hline Schools & 00 & 03 & 80000 & 35000 & 45000 & 56 \\
\hline Households & 00 & 143 & 4500 & 1500 & 3000 & 67 \\
\hline Prisons & 00 & 01 & 90000 & 25000 & 65000 & 72 \\
\hline Entreprises & 00 & 01 & 55000 & 15000 & 40000 & 72 \\
\hline TOTAL & 00 & 150 & 304500 & 101500 & 203000 & $67 \%$ \\
\hline
\end{tabular}

Table 2:- Income gaining activities and expenditure before and during biogas production

Source: field work, 2016.

Table 2 shows that before the arrival of biogasthe population of the study area depended solely on fuelwood and other energy sources (kerosene, sawdust, cow dung etc). As revealed in the field, inhabitantsmade use of diesel or kerosene consuming apparatus to provide the necessary energy for cooking or heating. The users of biogas energy usually spent huge sums of money but today there is considerable reduction in the amount of money spent with an average of $67 \%$ gained through biogas energy production. Households represent the highest consumers of biogas (143) spread over $65 \%$ villages; this source of fuel is mostly used for cooking.It was however noticed in the field that the reason users decided to procure biogas energy as seen above, was because it permitted them to economise and even generate some revenue which helps them in compensating for their spending.

\section{Health / Sanitation.}

Biogas energy ensures the functioning of about $45 \%$ of health sectors in the study area especially when there is failure in Hydro Electricity Power supply. However, boosting the health sector permits the continuous function ofsome health care apparatuses and lighting. These schemes reduce the exposure and vulnerability of households to diseases related to other dirty sources of energy especially from indoor air pollution. Burning of solid fuels such as biomass fuels (fuel wood), dung, crop waste and coal at home and the resulting smoke is associated with the prevalence of a variety of indoor air pollution diseases such as lower respiratory disease, chronic obstructive pulmonary disease, cancer and others. However, the usage of biogas prevents the prevalence of air pollution diseases [17].

In rural households in the NWRC where the use of biogas replaced the use of fuel wood, $94 \%$ of persons above the age of 55 affirm that they had bronchitis and ophthalmological problems in the era when they were using fuel wood; but today, they no longer have the challenge despite the fact that they have not been to the hospital. The reason is that their eyes and lungs are not in contact with smoke from fuel wood and plants wastes when burnt for 
heating.The use of biogas fuel reduces the risk of respiratory track infections and eye problems that results from smoke from fuel wood as well as kerosene fuel. This is because its fuel contains toxic substances. It therefore ensures energy security [22].

The social acceptance of biogas is often hampered by health concerns. When the process of biogas production is not well managed, pathogens can infect the rural population through agriculture. This becomes acute when the number of agricultural biogas plants and higher amount of digesters spread on agricultural land. This is because some pathogens are able to persist virtually unaffected due to the ability to build resistant permanent walls. Bacterial infection agents can contaminate humans through agricultural biogas plants that are poorly managed in an agrarian landscape. In such situations, crops grown as well as animals such as cattle, pig, and poultry act as the main source of contaminated food [22].

\section{E. Environmental protection.}

Biogas is now a safety valve in environmental protection as it now obviates the need for fuel wood collection reducing deforestation of montane forest and degradation as well Eucalyptus replacement with environmental friendly trees. Biogas reduces the environmental risk related to animal wastes thus promoting sustainable development[17].Biogas energy from an environmental perspective has a great impact on the lives of its users. It has been reported that biogas schemes had reduced the rate of fuel wood fetching in households with these plants by about $40 \%$. Biogas technology helps improve the livelihoods of the poor in rural areas with cost saving from replacement of firewood and chemical fertilizers; it contributes to the reduction of odouranimal dropping where animal housing is located, protects air quality by reducing smoke from cooking and helps minimize carbon emissions from burning firewood [19]. In this same line, [6], says that biogas contributes to Sustainable Development Goals such as carbon emission reduction, elimination of rural energy poverty.

With the advent of biogas schemes in the study area, cattle rearersare now shifting towards enclosed paddocks and ranches instead of the usual transhumance curbing the rate of environmental degradation that has for over decades been caused by this practice. Furthermore when animals are reared in ranches it facilitates dung collection while the biogas plants produce insecticides used on crops and drives flies that are often irritant to the animals and rearers.The atmosphere is purified as dung odour is reduced in the communities where these plants are found. In a nutshell, biogas production helps in the fight against environmental degradation, safes watershed, mitigates deforestation.

\section{F. Climate change mitigation}

Amongst the myriad of strategies to fight against the effects of greenhouse gases on climate change are renewable energies (REs). Recently it has been noticed that the use of biogas could be remarkable in mitigating the effects of climate change on the globe. It therefore becomes imperative to adopt REs into greenhouse gas emission reduction programmes through biogas schemes. Biogas energy containsmethane which is a greenhouse gas whose global warming power is estimated to be 28-36 times higher than $\mathrm{CO}_{2}$ over 100 years. As such, it is the second major component among anthropogenic greenhouse chemicals [23]. These are emissions that would have been sent into the atmosphere but are destroyed during biogas energy consumption mitigating the effects of such substances on greenhouse effect and consequently climate change.With must sub-Saharan African countries thriving to develop sustainably, the path to this development is the adoption of clean energy. Biogas thus contributes effectively to global sustainability by mitigating GHGs (Green House Gases) and significant provision of sustainable energy supply.

Globally, in 2004, it was remarked that $26 \%$ of global emissions were linked to electricity production and transportation [24]. Meanwhile the use of REs reduces over dependency on fossil fuels. In addition, the adoption of energy best practices and products greatly minimise the use of fossils as energy. The availability of biogas in the NWRC provides an essential possibility for the region to surmount the challenges of climate change. In the field notice was made of the fact that private individuals were resolving their energy issues themselves through the installation of biogas schemes.

With an average altitude of $1600 \mathrm{~m}$ above sea level, the NWRC presents a great biogas potential that can be harnessed in the fight against climate change(Atlas of Cameroon 2014). In fact, fuel wood fetching is amongst the major drivers of deforestation and forest degradation. Field experience showed that about $95 \%$ of biogas schemes used animal dung (cow, goat, sheep, pig) for biogas production. This due to a favourable climate and vegetation coverage has rendered biogas production possible in the region.This is an added advantage in climate change mitigation as the animals are not constantly grazing in the fields minimizing the effects of over-grazing which at times leaves land without any vegetation cover and thus facilitates erosion processes. In the field animal rearers involved in biogas production testified they had motorbikes they use to fetch grass for their animals. Eventhough, they complain that the activity is at times very tedious and involves very huge financial expenses, the energy they obtain from vegetables and assorted dairy products compensates for the losses incurred

\section{CONCLUSION}

Biogas energysignificantly contributes in improving rural livelihoods through its environmental, economic and health benefits. Its role in crop cultivation and climate change mitigation cannot be over-emphasized as illustrated above. Considering the aftermaths of biogas production, precaution measures should be taken in handling slurry to abate contamination from pathogens. Further studies are needed in order to render biogas energy storage possible and flexible. This will prevent biodigesters from explosion 
and methane losses into the atmosphere rendering the sustainability of plants questionable.However, the use of Biogas energy is growing rapidly with is associated impacts on livelihoods improvingincomes gained by households; thereby improving rural livelihoods.

\section{ACKNOWLEDGMENTS}

Special thanks to SHUMAS, SNV, Hiefer Project International for their collaborative support in conducting the research in the NWRC.More applause to Cameroon's Ministry of Environment and Nature Protection forgrantingus accesstoits library. We extend gratitude to some Cameroon scholars who provided viable information on biogas issues. Finally, this paper would not have been possible without the friendly support of biogas users who helped us enormously in understanding biogas energy production.

\section{REFERENCES}

[1]. Shams DilawarFarhan, Qasim Afghan Muhammad, Khalid Salma, Shah Kamran Hussain (2014). Impact of Biogas on Sustainable livelihood in Rural Areas. A Case Study of Swat, Pakistan. Journal of Applied Environmental and Biological Sciences. www.textroad.com. textRoad Publication. 4(8s) 2833. $7 \mathrm{p}$

[2]. MustonenSuvisanna, RaikoRisto, Luukkanen, (2013). Bioenergy Consumption and Biogas Potential in Cambodian Households Sustainability. ISSN 20711050 www.mdpi.com/journal/sustainability 5, 18751892; doi: 10.3390/su5051875. 18p

[3]. Ngala, R.M., (2013). The contribution of local hydroelectricity generation in the socioeconomic development of Kingomen-Kumbo. North West Region-Cameroon.169p.

[4]. SHUMAS, (2016). Annual report. 83p.

[5]. Chun, Y.N., Yang, Y.C., Yoshikawa, K., (2009) hydrogen from biogas reforming using gliding arc plasma-catalyst reformer. Catalysis Today. 148(3). P 283-289

[6]. AroduduOludunsin, Helming Katharina, Wiggering Hubert, VoinovAlexes, (2016). Bioenergy from lowintensity Agricultural Systems: an Energy Efficiency Analysis. Energies, MDPI. 18p

[7]. Chen, Q. and Liu, T. (2017). Biogas System in Rural China,. Upgrading from Decentralised to Centralised? Renewable and Sustainable Energy Reviews, 78, 933944.

[8]. Kozlowski, K., Lewick, A., Cieslik, M., Janczak, D., Czekala, W., Smurzyńska, A., Brzoski, M., (2017). The possibility of improving the energy and economic balance of agricultural biogas plant. TechnikaRolniczaOgrodnics a Leśna, 3, 10-13.

[9]. Bui, X.A., (2002). Biogas Technology in Developing Countrues: Vietnam case study. http://www.mekarn.org/procbiod/an.html . Accessed June 30, 2013.
[10]. KeovlayPhonephachanh, (2012). Household Biogas Technology to Improve Rural Livelihoods in Laos. Journal of Developments in Sustainable Agriculture. 7: 158-163.

[11]. CzekalaWojciech (2018). Agricultural Biogas Plants as a chance for the Development of the Agri-Food Sector. Journal of Ecological Engineering. Vol 19, issue 2. Pages 179-183. 5p.

[12]. Sasse L.V., (1998). Biogas Plants; a publication of the DeutschesZentrumZusammenarbeit (GTZ) Gmbit (Crossref)

[13]. Minde, Gauri P., MagdumSandip S., Kalyanraman, V., (2013).Biogas as a sustainable Alternative for Current Energy Need in India. Journal of Sustainable Energy and Environment. 4. 121-12. 12p.

[14]. East Consult, 2004). Biogas users survey of 2003/2004, Alternative Energy Promotion Centre.

[15]. Myles R., (2004). Environmental, Social and other Positive Impacts of Building household Biogas Plants in Rural India. In second World Renewable Energy Forum on Renewing Civilisation by RenewableEnergy. Bonn, Germany.

[16]. Gautam, R., Baral S., Herat S., (2009). Biogas as a Sustainablee Energy Source in Nepal: present status and future challenges. Renewable and Sustainable Energy Reviews. 13 (1). P. 248-252. 5p

[17]. Engler, C.R., et al (1999). Economics of Environmental Impact on Biogas Production as Manure Management Strategy. In Texas Animal Manure Management Conference: 1999 proceedings. Texas A\& M University, College Station, T X, USA

[18]. Li, Z., Xia, C., Luo, H, Zhong H., (2005). Towards gren rural energy in Yunnan, China, Renewable Energyy 30 99-108. 12p.

[19]. IFAD, (2007). Using Biogas Technology, farmers in Eritea help reduce greenhouse gasemissions.http:www.ruralpovertyportal.org/countr y/voice/tags/eritea/eriteabiogas. Accessed June 18, 2012.

[20]. GoldembergJose, Thomas B. Johansson, Amulya K.N Reddy, Rober H. Williams, (2004). Aglobal clean cooking fuel initiative. $8 \mathrm{p}$.

[21]. Ruth D., Wougang .B. (2012). An economic assessment of Biogas production and land use under the German renewable energy No. 1767

[22]. Bianca, F., Monika, H., Michael, L., Messlhauser, Matthias, P., (2015). Hygiene and sanitation in Biogas plants.

[23]. Valerio Paolini et al, (2012).Environmental impact of biogas: A short review of currentknowledge. $9 \mathrm{p}$.

[24]. Ugwuoke, P.E., Agwunobi, A.O, and Aliyu, A.O., (2012). Renewable energy as a climate change mitigation strategy in Nigeria. International Journal of Environmental Sciences (IJES). Vol 3(1), 11-19, p.9 